\title{
FRIEDRICH ENGELS E A QUESTÃO DO MÉTODO NO MARXISMO
}

\author{
FRIEDRICH ENGELS Y LA CUESTIÓN DEL MÉTODO EN EL MARXISMO
}

\section{FRIEDRICH ENGELS AND THE QUESTION OF THE METHOD IN MARXISM}

\author{
DOI: http://dx.doi.org/10.9771/gmed.v12i3.39287
}

André Figueiredo Brandão ${ }^{1}$

\begin{abstract}
Resumo: O argumento em questão parte da própria figura de Friedrich Engels como uma personificação das oscilações da tradição teórica da filosofia da práxis em seu lidar com o seu próprio método. De tal modo, concebe-se que há, no desdobramento da obra do filósofo alemão, uma tensão entre uma visão codificada e apriorística do marxismo; e uma forma mais acurada de encarar o seu modo de ser, enquanto um método que busca extrair as suas resoluções do próprio movimento do objeto. Por meio da análise de tal dualidade, objetiva-se ressaltar os elementos vivos e não mecânicos de um método possível para o marxismo, na contramão das experiências manualescas do século $\mathrm{XX}$, que ainda ecoam em nosso tempo.
\end{abstract}

Palavras-chave: Engels, Marxismo, Método.

Resumen: El argumento en cuestión parte de la figura de Friedrich Engels como personificación de las oscilaciones de la tradición teórica de la filosofía de la praxis cuando el tema era precisamente su propio método. Así, el texto explora cómo, en el despliegue de la obra del filósofo alemán, existe una tensión entre una visión codificada y apriorista del marxismo, y una forma más precisa de mirar su forma de ser, como método que busca extraer su resoluciones del propio movimiento del objeto. Por medio del análisis de tal dualidad, el objetivo es enfatizar los elementos vivos y no mecánicos de un posible método para el marxismo, frente a las experiencias manualescas del siglo XX, que aún resuenan en nuestro tiempo.

Palabras clave: Engels, Marxismo, Método.

Abstract: This argument starts dealing with the figure of Friedrich Engels as a personification of the oscillations of the theoretical tradition of the philosophy of praxis when approaches its own method. Thus, the text explores how, in the deployment of the work of the German philosopher, there is a tension between a codified and an aprioristic view of Marxism, and a more accurate way of looking at his way of being, as a method that seeks to extract his resolutions of the object's own movement. Through the analysis of this duality, the objective is to stand out the living and nonmechanical elements of a possible method for Marxism, against the encoded experiences of the twentieth century, which still echo in our time.

Keywords: Engels, Marxism, Method.

\section{Engels e a questão do método: primeiras considerações}

A questão do método no interior do marxismo nunca foi um ponto pacífico. Nos últimos tempos, observada a lenta mas significativa reapropriação e reinserção da filosofia da práxis nos debates teóricos nacionais, parte das discussões agitadas neste movimento concentraram-se neste eixo, tratando, nem sempre com o rigor necessário, de querelas como a existência ou não de um método para a perspectiva marxista; como seria composto este pretenso método; e até mesmo qual seria o estatuto epistêmico das resoluções metodológicas originadas por Marx e Engels, isto é, qual seria o peso da adoção de tal caminho investigativo para a riqueza e precisão de determinado estudo. 
O repúdio sistemático sofrido pelo marxismo, por meio dos mais diversos grupos que circulam no tecido social, tais quais os liberais e os conservadores, acaba por levar parte dos seus entusiastas a uma reafirmação fetichizanante da linha teórica, chegando ao limite de considerar a adesão a tal método como uma espécie de critério de verdade. Em outros termos, uma contribuição teórica, independentemente dos seus méritos, poderia ser rejeitada ou endossada de acordo com a sua proximidade com as teses propostas por Marx e Engels. Devido a tal fenômeno, a discussão em torno da elucidação dos contornos de um método marxista ganha maior importância no debate intelectual, de modo que se possa evitar que o uso da perspectiva confunda-se com a entrada em uma seita, e, ao mesmo tempo, que o seu uso não congregue certas manobras de "reestruturação" que simplesmente resultam no esvaziamento da filosofia da práxis, negando o método em abstrato ou vinculando-o sem nenhum rigor a outras formas investigativas, conduzindo a pesquisa à composição de uma síntese eclética, sem uma estruturação coerente e eficaz.

A ocasião do bicentenário de Friedrich Engels é propícia para a retomada de tal discussão, uma vez que uma via possível para o enfrentamento da questão perpassa pela compreensão da própria figura do filósofo alemão como ferramenta de investigação do fenômeno, uma vez que ele personifica em sua trajetória os usos e abusos do método marxista. Engels encarna em sua oscilante série de intervenções no debate pela consolidação da teoria marxista vários problemas que ganharam ampla centralidade no circuito histórico do marxismo, ao mesmo tempo que propõe diversas alternativas mais sofisticadas e esclarecedoras aos próprios desvios que cometeu. Assim, há que se reposicionar o teórico na trajetória do debate intelectual, como um investigador de pensamento próprio, e não apenas um segundo violino, um auxiliar de Karl Marx; não só como aquele que estimulou certos desvios que em tese o seu parceiro intelectual não cometeu, como muito se pensa na teoria marxista, mas também como um observador arguto que anteviu e combateu diversas vulgarizações que ganharam corpo num tempo posterior ao seu período produtivo.

Não há como falar da relação de Engels com a ideia de método sem tratarmos de sua relação com Hegel. Ao buscar estabelecer um juízo acerca da obra hegeliana, o autor considera justamente o método o lado revolucionário da contribuição do filósofo da suprassunção (ENGELS, 1962b, p. 292). É tão forte a inspiração de tal abordagem para o marxista que ele chega a denominar a sua concepção teórica da mesma forma como caracteriza a perspectiva hegeliana: enquanto "método dialético (dialektischen Methode)" (ENGELS, 1975b, p. 8). Para Engels, é esta construção ricamente sistematizada por Hegel a ferramenta necessária para que uma investigação escape à petrificação e ao isolamento proposto pela tradição metafísica da história da filosofia, contrapondo-a com a necessidade da conexão íntima do objeto com os determinantes de sua trajetória, marcada por um devir no qual há gênese, fenecimento e transformação, de modo que o seu olhar sobre o real não o seja mais regido por um emaranhado caótico de barbaridades sem qualquer vínculo, a serem impiedosamente condenadas por um tribunal da razão amadurecida (ENGELS, 1975b, p. 20-23). Assim, Hegel promove de maneira original uma leitura histórica do percurso humano, ainda que abstrata e idealista, e é precisamente aí que reside a sua mais importante contribuição (ENGELS, 2008, p. 279).

A obra hegeliana significou uma ruptura radical com a forma de desenvolvimento da pesquisa que a tradição filosófica consolidou. Hegel não aceitava a separação radical entre o conhecer e o real, proposto 
pelo kantismo de sua época. De tal sorte, não haveria mais espaço para o raciocínio que antevê uma prioridade da filosofia pôr-se de acordo com o conhecer antes de abordar diretamente a coisa a ser investigada (HEGEL, 2014, p. 69-70). Sem se contentar com uma linha divisória nítida entre estes dois campos pretensamente cindidos, o filósofo defende o envolvimento recíproco entre tais esferas. Não haveria a necessidade do estabelecimento de um padrão de medida apriorístico que trabalhasse a faculdade do conhecer dissociada do próprio processo de maturação do conhecimento de algo (HEGEL, 2014, p. 7577). Por tal perspectiva, Hegel admite que um raciocínio só é exitoso justamente quando se entrega ao real e enriquece o seu conhecer quando estrutura-se segundo a própria coisa, quando diz: "ao pensar, eu renuncio à minha particularidade subjetiva, aprofundo-me na coisa, deixo o pensar atuando por si mesmo. E eu penso mal, quando acrescento algo meu" (HEGEL, 2007a, p. 80-81). Há, portanto, uma forte tendência imanentista e não apriorística no pensamento hegeliano, que o leva ao entendimento de que "o mundo suprassensível é apenas a fuga do mundo sensível" (HEGEL, 2007b, p. 158). É esta tendência interna do raciocínio hegeliano, que torna a teoria possível uma teoria post festum, que o leva à célebre passagem sobre o pássaro de Minerva:

Para dizermos algo mais sobre a pretensão de se ensinar como deve ser o mundo, acrescentaremos que a filosofia chega sempre muito tarde. Como pensamento do mundo, só aparece quando a realidade efetuou e completou o processo da sua formação. O que o conceito ensina mostra-o a história com a mesma necessidade: é na maturidade dos seres que o ideal se ergue em face do real, e depois de ter apreendido, o mundo na sua substância reconstrói-o na forma de um império de ideias. Quando a filosofia chega com a sua luz crepuscular a um mundo já a anoitecer, é quando uma manifestação de vida está prestes a findar. Não vem a filosofia para a rejuvenescer, mas apenas reconhecê-la. Quando as sombras da noite começaram a cair é que levanta voo o pássaro de Minerva. (HEGEL, 2000, p. XXXIX)

Em suma, Hegel possui, dentre a série de matizes de seu sistema, um movimento em torno da construção de universais concretos, os quais a sua totalização é posta como resultado de seus próprios desdobramentos, em sentido distinto de uma forma de consolidação de um universal abstrato que aprioristicamente determina todos os momentos de sua circulação efetiva (HEGEL, 2014, p. 33-34). É certo que, ao vermos Hegel comportando-se em seu plano geral, podemos concordar com a visão lukacsiana de que a obra hegeliana vive a contradição entre um núcleo dialético-ontológico, que o aproxima diversas vezes de uma perspectiva materialista; e a construção lógico-hierárquica de um sistema, tensão conceitual que muitas vezes se torna uma questão intencional para o próprio filósofo (LUKÁCS, 2012, p. 242). Em um destes momentos, a argumentação hegeliana chega à ideia de que "a essência deveio a partir do ser e o conceito deveio a partir da essência, com isso, ele deveio a partir do ser", num movimento teórico que flerta com a tese eminentemente materialista da realidade como o fator ontologicamente primário, mas, imediatamente em seguida, tal esboço é deixado de lado, assim que Hegel assume tal devir como contrachoque de si mesmo, "de modo que o resultado do devir é, antes, o incondicionado e originário" (HEGEL, 2018, p. 66).

Por mais que Engels considerasse que o fator que prevalece na obra hegeliana é o seu lado revolucionário, isto é, a natureza dialética desse método, que o contrapõe às manifestações metafísicas do pensamento, há em Hegel, em sua avaliação, a ideia de que o movimento do real é governado pelo conceito, 
como se a circulação observada do mundo se movesse segundo o autodesenvolvimento do conceito, conduzido pelo processo da realização progressiva da ideia absoluta, anterior ao mundo e independente dele, de tal modo que, aos olhos engelsianos, o conteúdo concreto observado por Hegel, encaixado em tais moldes, é considerado uma espécie de materialismo posto de cabeça para baixo de forma idealista, conduzindo assim a sua exposição a um triunfo da lógica arbitrária sobre a história efetiva (ENGELS, 1962b, p. 267-268, 277, 292-293).

A observar em Hegel tais limitações, Engels não se propõe a salvar o método hegeliano. Para o materialista, não é possível separar o que há de velho e o que há de novo no sistema analisado, cabendo então apropriar-se das suas melhores ferramentas para estabelecer uma nova perspectiva (ENGELS, 1962b, p. 291-292). Assim, o filósofo se põe em acordo com a proposição de Marx n’O capital acerca da necessidade de apropriação do cerne racional do método dialético hegeliano, despojando-o de seu invólucro místico (MARX, 1988, p. 26-27). Por meio de tal balanço crítico, o movimento observado pela teoria não seria a apreensão do automovimento de um conceito externo ao mundo objetivo, mas a assunção do movimento efetivo da realidade objetiva pela teoria, como já esboçada na faceta racional da teoria hegeliana, mas indo além dela (ENGELS, 1962b, p. 292-293).

Neste processo de crítica à manifestação idealista do método hegeliano, Engels não teve a mesma capacidade que Marx de estabelecer um desenvolvimento intelectual autônomo frente às considerações do filósofo da suprassunção. É certo que o filósofo de Trier cometeu certos desvios durante o seu desenvolvimento, como em uma passagem sintomática d'O capital em que diz que

O possuidor de dinheiro ou de mercadorias só se transforma realmente em capitalista quando a soma mínima adiantada para a produção ultrapassa de muito o máximo medieval. Aqui, como nas ciências naturais, comprova-se a exatidão da lei descoberta por Hegel, em sua Lógica, de que modificações meramente quantitativas em certo ponto se transformam em diferenças qualitativas (MARX, 1988, p. 234)

Engels, contudo, vai além, ao codificar o pensamento hegeliano aquelas que seriam chamadas de leis da dialética: a lei da transformação da quantidade em qualidade e vice-versa; a lei da interpenetração dos contrários; e a lei da negação da negação (ENGELS, 1975c, p. 348). Esta última, inclusive, nas considerações do marxista presentes no Anti-Dühring, tencionaria um caminho inevitável de melhora qualitativa no desenvolvimento dos choques materiais, indicando um aperfeiçoamento linear dos seres naturais e sociais (ENGELS, 1975b, p. 126-127).

Esta posição pouco autônoma do filósofo alemão frente a Hegel entra em conflito com a sua oposição a certas tendências já existente em sua época que tinham como objetivo dar tons positivistas e neokantianos ao marxismo. Tais perspectivas concebiam a necessidade da aplicação de um quadro a priori na realidade objetiva, por diversas vezes criticada por Engels (LUKÁCS, 2010, p. 330-331), propondo assim uma filosofia da práxis imbuída de um metodologismo que manipula o real, imprimindo em sua dinâmica operativa categorias dogmáticas e previamente constituídas. O teórico materialista buscou a todo momento se contrapor a tal faceta do marxismo, defendendo a sua apropriação crítica da natureza mediativa e da fluidificação dos conceitos promovida pelo idealista alemão. Engels, contudo, acaba por assumir o mesmo fenômeno com um sinal trocado, uma vez que, em sua justa defesa do legado hegeliano para o marxismo, 
produziu uma terrenificação da lógica hegeliana, ao seguir a sua convicção teórica acerca da necessidade de "colocar Hegel de pé", como corolário da sua já citada interpretação da filosofia de Hegel como um materialismo idealisticamente posto de cabeça para baixo (LUKÁCS, 2010, p. 166-168).

Deste modo, a lógica hegeliana subjaz clandestinamente em parte dos raciocínios engelsianos, agregando em seu composto teórico largos elementos do idealista alemão, em vez de solidificar uma nova alternativa que de fato reelaborasse o conjunto de ideias já posto em torno de uma nova abordagem autônoma. Ao assumir de maneira supostamente materialista um alto grau de considerações hegelianas, Engels oscila entre uma manifestação crítica aos métodos logicistas, isto é, às codificações e elaborações apriorísticas, e uma adesão ingênua aos seus traços que, em diversos momentos, o leva a interpretar o decurso da sociedade do ponto de vista de uma necessidade lógica (LUKÁCS, 2017, p. 137), subsidiando de maneira não intencional o tipo de logicismo tanto criticado por ele na última fase de sua vida, proveniente daqueles que viriam a atuar na chamada Segunda Internacional.

\section{Quando o metodologismo tomou posse do marxismo}

A obra de Eduard Bernstein funciona como espécie de síntese da trajetória argumentativa que tanto preocupava o último Engels. O teórico e político alemão foi um grande propagandista da corrente neokantiana dos movimentos de esquerda da passagem do século XIX para o início do século XX, dizendose convencido de que a democracia social requeria um Kant (BERNSTEIN, 1997, p. 159). Esta predileção resulta de uma clara contraposição aos elementos hegelianos da filosofia da práxis, uma vez que o socialdemocrata era um defensor da tese de que o que Marx e Engels realizaram de grande não conseguiram graças à dialética hegeliana, mas apesar dela (BERNSTEIN, 1993, p. 46).

Lukács argumentava que o combate à dialética vinculava-se ao aumento do ceticismo de certo contingente do movimento social com relação a elevação da perspectiva do horizonte político, proporcionada pelo materialismo histórico, para além da imediaticidade da ordem social posta, de modo a apresentar um campo de ação circunscrito à esfera do vigente (LUKÁCS, 2015, p. 83). Bernstein acenava para tal diagnóstico, na medida em que criticava as correntes não hostis ao hegelianismo, dizendo que estas seriam uma forma de calvinismo sem deus (BERNSTEIN, 1997, p. 34), por acreditarem em uma utopia construída por meio de um "idealismo especulativo" que continha um elemento não demonstrado cientificamente (BERNSTEIN, 1997, p. 11). Logo se pode perceber os critérios neopositivistas que o socialdemocrata alemão apresentava daquilo que poderia ser cientificamente verificável e aquilo que seria um tipo de idealismo especulativo: não haveria por tal via uma possibilidade de verificação científica daquilo que está para além da mera datidade.

O desfecho político de tal raciocínio dá razão aos argumentos de Lukács, uma vez que Bernstein, com base nas suas apropriações do neokantismo, asseverava que "o que geralmente se chama de fins últimos do socialismo é nada, mas o movimento é tudo" (BERNSTEIN, 1997, p. 147). Há, por este turno, uma subordinação do horizonte estratégico pela tática, da elaboração enriquecida de determinações pelo dado imediato, conduzindo as suas considerações para afirmar que "a tarefa da democracia social é ainda por 
muito tempo lutar por todas as reformas no Estado que se adaptem a erguer as classes obreiras e transformar o Estado na direção da democracia” (BERNSTEIN, 1997, p. 26).

É este tipo de raciocínio que Lukács identifica como a raiz dos desvios metodologizantes encorajados institucionalmente pelo regime staliniano, como reminiscências que foram rearranjadas sob as novas condições de um governo de um partido de esquerda. Assim, as tendências vivas da social-democracia de cunho bernsteiniano foram apropriadas e reformuladas a partir desta nova dinâmica dos movimentos sociais, da antiga adaptação da social-democracia a chamada realpolitik dos marcos postos pela democracia liberal até a ascensão ao governo no caso soviético (LUKÁCS, 2011, p. 134).

A apoteose de tais tendências do movimento social ocorre justamente com este assentamento do Estado soviético sob a liderança de Stalin, quando o método da filosofia da práxis codificou-se, tornandose filosofia de Estado, como o resultado final de um uma trajetória histórica em que enfim a razão seria coroada, ao ser encarnada como ideologia institucional. É curioso que, mesmo que em tais tendências, tanto na sua manifestação segunda internacionalista quanto no regime staliniano, por mais que repudiassem firmemente o legado de $\mathrm{Hegel}^{2}$, seu movimento prático adquire teor fortemente neohegeliano, na medida em que terrenifica teses do último Hegel, em seu Princípios da filosofia do direito, quando este prevê a realização da eticidade através da ação racional do Estado (LEFEBVRE, 1991, p. 3-4). Como argumenta Lefebvre (1991, p. 15-16), esta construção termina por gerar o eclipse da dialética marxista, na medida em que redireciona o seu expediente para a sua instrumentalização segundo os interesses do governo, tendo a sua margem possível reduzida ao quadro institucional estabelecido, perdendo assim a negatividade intrínseca da perspectiva teórica marxista, apresentada por Marx n’O capital, quando diz que a dialética,

Em sua configuração racional, é um incômodo e um horror para a burguesia e para os seus porta-vozes doutrinários, porque, no entendimento positivo do existente, ela inclui ao mesmo tempo o entendimento da sua negação, da sua desaparição inevitável; porque apreende cada forma existente no fluxo do movimento, portanto também com seu lado transitório; porque não se deixa impressionar por nada e é, em sua essência, crítica e revolucionária. (MARX, 1988, p. 27)

O resultado apresentado por tal experiência foi expresso no romance Um belo domingo, de Jorge Semprún (1982, p. 155), onde se pode ler que “a dialética [...] é a maneira de sempre cair de pé.” De tal sorte, o marxismo sofreu uma conversão que o pôs como técnica manipulatória, rigorosamente comprometida por determinações puramente administrativas, na qual o fundamento teórico de cada decisão prática surge como justificação do que o governo decide realizar, frequentemente posta como um conjunto de sofismas, emulando uma continuação ou aplicação mecânica do quadro metodológico previamente esboçado (LUKÁCS, 2011, p. 125-126). Assim, o método marxista é aprisionado em um esquema de domesticação, na contramão do que pode ser encontrado nas Teses sobre Feuerbach, em que o próprio educador deve ser educado e o processo formativo encontra-se no interior da própria dinâmica concreta de transformação efetiva da vida social (MARX, 2009, p. 119). Em seu lugar, o marxismo domesticador propõe a transformação dos indivíduos singulares por meio da ação unilateral de um agente manipulatório do comportamento alheio (KONDER, 1988, p. 39-40). Como elemento auxiliar de tal processo, a educação dos indivíduos, em via de mão única, era pensada conferindo papel fundamental à absorção dos diversos 
manuais produzidos à época, que tratavam de vulgarizar o método e aproximá-lo de algo que pudesse ser reproduzido mecânica e universalmente, distorcendo cada realidade particular.

Neste processo, o marxismo soviético passa a cada vez mais convergir com o positivismo, ao assumir uma postura resignada de autolimitação ao dado imediato, fetichizado, dotado de uma lógica fatalista não passível de alteração segundo a ação humana (KONDER, 1988, p. 182), ao mesmo tempo que a exigência das demandas institucionais promovia um voluntarismo que pudesse subsidiar as ações tomadas pelo regime, por mais arbitrárias que pudessem ser. Assim, para legitimar e compatibilizar esta mescla eclética entre voluntarismo e positivismo fatalista, a ideia de etapa adquire centralidade no pensamento da época, de forma a conferir uma ampla margem de atuação para o partido de acordo com a circunstância histórica em questão, para que possa seguir corretamente a lógica inexorável que em tese vive subrepticiamente no tecido social, lembrando de maneira sintomática a ideia de Auguste Comte ${ }^{3}$ dos estágios da história humana (KONDER, 1988, p. 182-183).

Em meio a tal lógica de redução do lastro teórico à mera imediaticidade, o marxismo vinculou-se de maneira fetichista à ideia de classe social. Foi estabelecida uma distinção entre interesse/ciência burguesa versus interesse/ciência proletária, de forma que, por um lado, houve a reprovação de conquistas da ciência ocidental, como a genética de Mendel, a partir da censura promovida pelo cientista soviético Lysenko; e o imperativo da proletarização de objetos científicos totalmente incapazes de assumir uma "posição de classe", como no exemplo dado por Lefebvre da exigência que havia em sua tempo de que fosse elaborada uma "lógica proletária" (LEFEBVRE, 1991, p. 1).

O fetiche pela classe, que a deforma e a hipostasia, constitui-se como um fenômeno hostil à perspectiva teórica desenvolvida por Marx e Engels. Engels, por exemplo, entendia que o marxismo deveria desenvolver a sua luta por via de três frentes, a saber, a ideológica; a econômico-sindical; e a política, mas sempre assumindo uma perspectiva científica, proporcionando assim o primado da análise objetiva frente às possibilidades de captura de um dado movimento do tecido social para os interesses de determinada classe em luta (ENGELS, 1960, p. 542). Mesmo quando abordou a questão moral, atestando a sua vinculação efetiva aos diversos interesses de classe, o filósofo alemão fez questão de ressaltar que a fronteira final da moralidade não seria uma espécie de moralidade proletária universalizada, mas sim uma moral humana, engendrada para além dos desvios que uma captura segundo os interesses de determinada classe podem conferir, assim que ocorresse a dissolução da divisão da humanidade em destacamentos sociais antagônicos (ENGELS, 1975b, p. 86-88).

O saldo destas manifestações deformadas de marxismo é o tipo de pseudoortodoxia marxista que se expressa através de um uso repetitivo de slogans radicais coagulados e mal compreendidos (LUKÁCS, 2012, p. 299). Podemos ver uma boa figuração deste fenômeno no filme $A$ chinesa (1967), no qual um grupo de jovens, ao lerem O livro vermelho de Mao Tsé-Tung, tomam a obra como um livro de provérbios, um guia de vida, utilizando de maneira totalmente arbitrária jargões da política marxista. Um exemplo disso pode ser visto em uma cena na qual um dos membros do núcleo retorna da rua ensanguentado, devido a um violento ataque perpetrado por um grupo de militantes de outro partido político, gerando como resposta a tal atentado uma fala orgulhosa de outro membro do conjunto atacado, declarando que aquela situação era 
resultado da "distinção dialética" existente entre os partidos. Ao observar o crescimento deste tipo de adoção caricatural do marxismo, Lukács dizia que esse fenômeno nada mais era do que um castigo, uma resposta dos movimentos sociais aos anos de educação promovidos pelo dogmatismo, pela ausência de princípios e pelo taticismo dos partidos comunistas da época, revelando o quão longe tais desvios poderiam ser levados (LUKÁCS apud KONDER, 1980, p. 100).

\section{A crítica ao metodologismo e a necessidade de um método de novo tipo}

Por conta destas manifestações metodologizantes, que se alastraram durante a primeira metade do século XX, muitos marxistas dedicaram parte do seu tempo à crítica ao uso deformado do método proposto por Marx e Engels. O filósofo brasileiro José Chasin, por exemplo, argumentou que

Se por método é entendido uma arrumação operativa, a priori, da subjetividade, consubstanciada por um conjunto normativo de procedimentos, ditos científicos, com os quais o investigador deve levar a cabo seu trabalho, então, não há método em Marx (CHASIN, 2009, p. 89).

O que Chasin queria não era a rejeição em absoluto da ideia de método, mas a contraposição às consequências da operação da filosofia da práxis por meio de uma plataforma especulativa (CHASIN, 2009, p. 92). A ideia de um método a priori é uma perspectiva metafísica da investigação humana que leva ao dogmatismo ou ao par relativismo/ceticismo, num esforço fundamental que nada mais é do que uma abstração desistoricizante e teoricista, que violenta a realidade de acordo com os interesses ou petições de princípio do investigador (TONET, 2013, p. 127).

É preciso, apesar da crítica ao metodologismo, defender uma concepção de método. Caso contrário, tomando como exemplo uma hipérbole, não há como contra-argumentar que seja plausível ou não a realização de estudos que busquem apreender as determinações fundamentais de dado fenômeno social olhando as formas das nuvens ou jogando dados. A negação da razoabilidade deste tipo de pseudociência só é possível a partir de uma compreensão de que haveria um método melhor para o desenvolvimento do processo investigativo em questão. De fato, se considerarmos a natureza do problema por uma perspectiva mais ampla, compreende-se a impossibilidade de qualquer investigação, por mais vulgar seja, sem uma ideia de método, seja ela evidente ou não intencional. A ausência de método traduz-se na pura espontaneidade, mas o olhar humano, desde as primeiras conquistas de seu processo de socialização, desenvolveu articulações não-espontâneas, ao munir-se com seus novos aparatos de mediação com a realidade ao seu redor. Os seus próprios sentidos, a partir da formação conformada ao longo do processo histórico, foram além das suas atuações rudes, naturalizadas, assim que assumiram contornos teóricos, enriquecidos pelos construtos socioculturais engendrados pela ação humana no curso da história, tornandose órgãos comunitários (MARX, 2015, p. 349-350). Deste modo, por mais que a visão natural de uma águia alcance distâncias maiores que a visão natural do humano, o desenvolvimento do aparato sensível do ser social o permite alcançar contornos de uma questão que o animal não humanizado jamais atingirá (ENGELS, 1975a, p. 447-448). 
A produção científica, como Marx afirma nos Manuscritos econômico-filosóficos, é mais um dos espaços de expressão da vida social, por mais isolada ou individual que ela possa parecer, uma vez que nós nos valemos do idioma, dos instrumentos, e das considerações pregressas para construir toda e qualquer investigação (MARX, 2015, p. 347-348). Depreende-se de tal maneira que há um processo de sofisticação social do olhar humano que, ao longo da trajetória da humanidade, possibilita à percepção do ser social a assunção de níveis qualitativamente superiores para seus propósitos investigativos. O método aparece nesse momento como a síntese possível, isto é, a sistematização do conhecimento que orienta o processo de descoberta a adotar caminhos que, sem as ferramentas que se pode assimilar, não haveria como progredir tanto quanto seria possível progredir em dado momento histórico. Assim, surge a tarefa do investigador apropriar-se, a partir das contribuições já postas no existente, dos melhores pressupostos para a realização de sua pesquisa.

O marxismo, de acordo com a sua dupla inaugural, não é um expediente teórico isento de pressupostos (Voraussetżungen). A diferença da estruturação de seu quadro conceitual para as outras linhas teóricas perpassa pelo fato de que as suas premissas não se apresentam como arbitrárias ou dogmáticas, mas sim como premissas reais (wirkliche Voraussetzungen), extraídas do movimento concreto do objeto (MARX; ENGELS, 1978, p. 20). O balanço histórico feito por Marx e Engels da produção científica de até então, segundo o olhar lukacsiano, tem como base a ideia de que há uma anterioridade do ser frente a consciência que a investiga, uma vez que o ser material existe sem a dinâmica consciente, mas a vida consciente, por sua vez, não pode existir sem ter como base o mundo objetivo anteriormente dado (LUKÁCS, 2012, p. 307). Em seu livro Ludwig Feuerbach e o fim da filosofia clássica alemã, Engels trata passageiramente dessa relação entre o ser e o pensar mobilizando parte dos debates da tradição filosófica, classificando o seu conjunto entre aquelas perspectivas que adotavam a visão de que há uma anterioridade das ideias ou do consciente frente o mundo material, enquanto perspectivas idealistas, e aquele grupo no qual o filósofo se incluiria, que atesta a anterioridade do ser material frente ao ser consciente, ou seja, adotando um ponto de vista materialista (ENGELS, 1962b, p. 274-275). Por tal via, a nova filosofia que se apresentava como síntese dos debates do tempo de Engels deveria contrapor as quimeras pré-concebidas que povoavam as teses daquela época com raciocínios que tratam a história a partir do encadeamento do ser-propriamente-assim ${ }^{4}$ do real. (ENGELS, 1962b, p. 292-293).

Este foi um movimento de ultrapassagem da filosofia da práxis, incorporando e colocando em novo patamar algo que já estava in nuce na filosofia hegeliana, a partir da compreensão já citada do mundo suprassensível como a fuga do mundo sensível. O que já estava esboçado em Hegel é explorado até as suas últimas consequências desde pelo menos os Manuscritos econômico-filosóficos, quando Marx constata que um ser não-objetivo é um não-ser (MARX, 2015, p. 376), invalidando assim o lidar teórico com qualquer elemento pretensamente supramaterial, de modo que um estudo necessita ater-se ao que efetivamente é o movimento imanente do seu objeto de estudo. A revolução teórica que parte de tal observação traduz-se na constatação de que "a reforma da consciência consiste unicamente em deixar o mundo interiorizar sua consciência, despertando-o do sonho sobre si mesmo, explicando-lhe suas próprias ações” (MARX, 2010, p. 72). Em outros termos, a tarefa da crítica filosófica seria forçar as "relações petrificadas a dançar, entoando a elas sua 
própria melodia” (MARX, 2013, p. 154). Na gramática engelsiana, isto significa apoiar as trajetórias teóricas que buscam explicar o mundo por ele mesmo (ENGELS, 1975c, p. 315), além da censura aos métodos que, no campo da teoria social, por exemplo, querem erigir um modelo alternativo de sociedade a partir de considerações extraídas diretamente do cérebro dos teóricos (ENGELS, 1975b, p. 241). Assim, os procedimentos da investigação não devem ser previa e arbitrariamente postos pela capacidade imaginativa do pesquisador, mas dados pela própria objetividade na qual se debruça o investigador (TONET, 2013, p. 112). É isso que Chasin (2009, p. 98) chamava de transitividade, uma vez que, nesta mediação entre sujeito investigativo e objeto investigado, há uma objetividade subjetivada, na medida em que é apreendida pelo investigador, e uma subjetividade objetivada, a partir do momento em que os mecanismos de absorção do movimento do real assumem como seus justamente as nuances que o objeto conforma em seu automovimento. É necessário perceber que, ao conceber que é imperativo que seja retirada a impressão imediata da petrificação da mera datidade, o marxismo não se configura como um realismo ingênuo, que assume como resultado final de sua investigação uma fotografia mecânica do que os seus dados empíricos “espontaneamente" aparentam ser. Entretanto, a superação da imediaticidade não pode se dar com movimentos arbitrários. Aí está a genialidade que a exposição de Marx demarca, uma vez que a forma como ele entende que as relações estanques precisam ser movimentadas e retiradas de um patamar coagulado precisamente segundo os ditames de sua própria melodia, isto é, só quando um estudo avança segundo as próprias categorias de um o objeto que ele pode atingir um plano de determinações mais rico.

Posta em tais mediações, a objetividade observada pelo marxismo não se confunde nem com a partícula imediata, estática e isolada, nem mesmo com uma ideia de ser abstrata, sendo assim entendida como um existente movente e movido no interior de um complexo concreto, numa concepção de objetividade que reúne não apenas a mera coisidade, abarcando igualmente as relações e conexões efetivas, sociais e naturais, assim como todos os experimentos da realidade que se apresentam imediatamente como produtos do pensamento (LUKÁCS, 2007, p. 226; LUKÁCS, 2012, p. 314). Há aqui uma profunda ruptura com a noção de substancialidade proposta de maneira hegemônica pela tradição filosófica, na qual a substância de um ente nada mais seria do que o seu conjunto de atributos imutáveis, sobre os quais a ação histórica não surte efeito algum. Em sentido contrário, o marxismo detém a compreensão de que a substancialidade de dado ente corresponde ao seu conjunto de determinações móveis, não metafísicas, que possuem o atributo da continuidade justamente pelo seu movimento e transformação em sintonia com o movimento geral, capazes de empreender alguma dinâmica de perdurabilidade (LUKÁCS, 2012, p. 339341). Por conta disso, a teoria originada por Marx e Engels, ao incidir sobre o ser social, afasta-se da ideia estático-naturalista proposta pelos hegelianos de esquerda de um homem em geral, ocupando-se de tal modo dos homens históricos reais (MARX; ENGELS, 1978, p. 42). Para o marxismo, o estudo do gênero humano perpassa pela investigação dos indivíduos reais em suas condições materiais de vida, tanto aquelas por eles já encontradas como as produzidas por sua própria ação (MARX; ENGELS, 1978, p. 20).

$\mathrm{Na}$ investigação a ser empreendida, é patente que o objeto denominado ser social possui uma série de peculiaridades que o distingue dos objetos puramente naturais, exigindo manejos diversos no trabalho investigativo. Engels neste caso também oscila entre uma posição consciente de tal trato diferenciado e uma 
unificação indevida entre os objetos e as perspectivas de pesquisa. É fato que o filósofo alemão assume que a realidade é una (ENGELS, 1962b, 277-278), num sentido similar à tese lukacsiana posterior, de que a humanidade não é nem um ser indistinguível nem radicalmente diferente das outras esferas de ser que compõem o real, permanecendo direta e irrevogavelmente em incessante coexistência com as esferas orgânicas e inorgânicas do ser, mas que, na trajetória de consolidação de sua especificidade, acaba gerando para si uma legalidade própria (LUKÁCS, 2012, p. 25; LUKÁCS, 2010, p. 36). Engels chega a(1967c, p. 135) criticar certa perspectiva de Podolinsky em uma carta a Marx, por sua tentativa de encontrar na ciência da natureza uma nova demonstração da verdade do socialismo, confundindo em tal movimentação a economia com a física. Esta carta atesta como o pensador materialista estava consciente de tais divisões, entre naturalidade e ser social (FREIRE JR, 1995, p. 29). Contudo, o autor acabou por aproximar indevidamente mecanismos dos fenômenos naturais dos fenômenos sociais em determinados momentos de sua obra (LUKÁCS, 2010, p. 187-189), como no já citado exemplo da terrenificação da "lei dialética" da negação da negação, presente de maneira indistinta nos seres naturais e sociais. O fato é que, pelo processo de consolidação de uma nova legalidade, que reestrutura a própria naturalidade corpórea humana e a naturalidade dos objetos movidos pelo gênero humano, o ser social desenvolve novos nexos que inegavelmente conformo um novo material inegavelmente menos inequívoco e mais oscilante, em termos lukacsianos, que impõe a necessidade de novos nuances para as investigações acerca do ser social (LUKÁCS, 2013, p. 153, 358).

Por conta disso, Marx distingue n'O capital a ciência sobre tal objeto daquele esmiuçado pelas ciências da natureza, que podem munir-se de experimentos laboratoriais, através do microscópio ou de reagentes químicos, legando a faculdade de abstrair a tarefa de substituí-los (MARX, 1988, p. 18). A abstração marxista não seria uma abstração qualquer, que pode promover inclusive uma carta de salvo conduto para as abstrações arbitrárias e metafísicas que o idealismo por vezes se vale. A abstração inscrita na filosofia da práxis é aquela que Marx classifica como abstração razoável, enquanto aquela que efetivamente destaca e fixa o elemento comum dentro das múltiplas manifestações de dado fenômeno, tornando-se um universal isolado pelo cotejo desta série de manifestações (MARX, 2011, p. 41). A necessidade de articular tal universal geral com a particularidade dada fundamenta-se no fato de que toda abstração razoável nada mais é do que um produto de relações históricas e que apenas possui a sua validade para essas relações e no interior delas (MARX, 2011, p. 44). Da mesma forma, o concreto, em sua aparição imediata, surge para a visão ingênua sob os moldes de uma representação caótica do todo, de um manejo de conceitos explicativos mais simples que enriqueçam a razoabilidade abstraída (MARX, 2011, p. 54).

Hegel nos ajuda a entender este movimento pois, ao mesmo tempo em que ele entende que compreender um objeto "não significa senão apreendê-lo na forma de algo condicionado e mediatizado" (HEGEL, 2007a, p. 140), também é fato que, para a dialética de inspiração hegeliana, a delimitação da verdade de um fenômeno em sua pura abstração é um esforço para torná-lo não-verdadeiro (LEFEBVRE, 1991, p. 111). Isto significa que não se pode confundir o efetivo do objeto com a sua datidade, da mesma forma que uma abstração pura, petrificada e desvinculada das próprias relações que permitem a operação intelectual que a gerou, nada mais é do que um esvaziamento, uma vez que o próprio filósofo da 
suprassunção admite que o despojamento de um ser das suas determinações nada mais é do que um movimento de nadificação (HEGEL, 2016, p. 85-86).

Em linguagem lukacsiana, isto significa que o senso materialista de realidade que deve permear a filosofia da práxis exige que o desenvolvimento das suas investigações precisa manter uma crítica e autocrítica ontológica que alie as abstrações analíticas necessárias para o estudo de um complexo, isolados provisoriamente de certas conexões categorias mais amplas, que promovem a sua plena explicitação e compreensão de legalidade internas próprias, com a totalidade de seu complexo nas suas relações e tendências objetivas, de modo que os componentes centrais estudados não se percam das inter-relações que os constituem enquanto tais (LUKÁCS, 2012, p. 310). O andamento de uma pesquisa necessita estar atento às devidas relações entre gênese e processo. Como argumenta Lukács, há no marxismo uma cooperação permanente entre o processo histórico genético de consolidação de um fenômeno e um procedimento abstrativo-sistematizante, que põe em evidência as suas leis e tendências (LUKÁCS, 2012, p. 287-288, 306). Com tal preocupação em mente, Engels critica os marxistas vulgares da sua época, justamente por defenderem um uso da teoria como uma alavanca destinada a erguer construções apriorísticas. Em sentido distinto, o autor concebia a filosofia da práxis como um guia de estudo de modo que não haja um quadro categorial que deforme a realidade para facilmente se encaixar numa resposta previamente concebida, mas sim que, em cada nova realidade, o conjunto de ferramentas intelectuais pressuposto, enquanto um guia para o estudo (Anleitung beim Studium), permita a investigação efetiva das minúcias de tal manifestação determinada do objeto social inserido no curso da história, para que este possa ser delimitado precisamente como se move (ENGELS, 1967a, p. 436-437). Só assim é possível afastar tanto o dedutivismo que deriva as formas mais imediatas de um universal abstrato especulativamente constituído, e nem se conceda margem para o tipo de consideração que entende que é o exercício mais simples de um fenômeno que dá um tom para todo o conjunto de manifestações subsequentes, na sua imediatidade isolada de seu conjunto de mediações.

Ao explicitar a lógica interna de dado objeto social, o método marxista, de acordo com Engels (1961, p. 474-475), nada mais faz do que expor as linhas mestras dos seus nexos constituintes retirando os elementos não essenciais de sua forma histórica e as casualidades inoportunas. O objetivo seria a captação e expressão plena das leis que impelem ao curso do real as principais tendências de seu desdobramento, de maneira que cada determinação específica possa ser examinada mediada pelos elementos de sua plena maturidade. É claro que tal exposição, como Marx compreende n'O capital, pode aparentar uma construção a priori, produto daquele que a expõe (MARX, 1988, p. 26). Contudo, a única sustentação possível desta falsa aparência decorre da separação arbitrária entre o modo de exposição e o modo de investigação de um estudo, algo que não é da natureza do método da filosofia da práxis.

Poucas investigações puderam esclarecer a dimensão do modo de exposição para o marxismo como nos estudos do filósofo Marcos Lutz Müller. Para o brasileiro, a noção central do método seria a própria exposição, não no sentido comum do termo, como um ordenamento do discurso voltado para as próprias questões concernente à enunciação como um fim em si, mas sim como um modo de explicitação do objeto apreendido em suas articulações próprias (MÜLLER, 1982, p. 1). A exposição marxiana, aos olhos 
de Müller, reconstrói no plano ideal o objeto de estudo, sem ser simplesmente diacrônico, numa totalidade que subordina o todo do objeto às suas relações simples, nem sincrônico, de sua reprodução puramente abstrata (MÜLLER, 1982, p. 2-4). Não seria então uma autodeterminação do conceito, mas a exposição das articulações sistemáticas de todas as relações do objeto que se implicam reciprocamente, apreendendo as determinações do conteúdo no próprio movimento pelo qual elas se desdobram, nas suas conexões necessárias e imanentes (MÜLLER, 1982, p. 5). A exposição é, portanto, a reconstrução categorial do automovimento do próprio objeto, que pressupõe um trabalho prévio de investigação que dê subsídio a exposição possível de sua lógica interna, justamente de acordo com os nexos que a análise apreendeu (MÜLLER, 1982, p. 9). Este vínculo entre investigação e exposição é aproximado de tal maneira que Müller conclui que há a necessidade de um método próprio para cada coisa, na medida em que ele necessita acompanhar a atividade de seu objeto segundo sua própria dinâmica (MÜLLER, 1982, p. 14).

\section{As investigações engelsianas e o curso da história}

Nas exposições do desenvolvimento de objetos sociais em sua trajetória histórica, há em Engels uma forte revolta contra a ideia de progresso vulgar, crítica a todo fatalismo ou lógica estacionária do processo histórico. O autor, por exemplo, celebrou as pesquisas de Darwin como um golpe irreversível contra qualquer tipo de na teleologia natural (ENGELS, 1978, p. 524). Como interpreta Lukács, a necessidade perde o seu sentido clássico no marxismo, passando a existir apenas na matemática, sendo possível apreender apenas uma natureza probabilística nas relações inscritas no real, dando margem apenas para a caracterização de certas vinculações como necessárias quando elas se constituem por meio de um nexo sob o formato de um "se... então", isto é, enquanto legalidade sempre concreta que se constitui no interior de uma relação condicional (LUKÁCS, 2017, p. 137; LUKÁCS, 2013, p. 145). Engels, na mesma direção que a leitura lukacsiana indica, admite a existência do acaso no movimento do real, enquanto acontecimento cuja conexão interna é tão remota, tão difícil de demonstrar que a pesquisa a considerou inexistente ou subestimou a sua força determinante, fazendo parte do perfazer do movimento histórico, de modo que a captação das linhas evolutivas tendenciais do automovimento do gênero humano não pode ser resumido a um motor surdo fatalista como a determinação econômica pura, o que tornaria a análise do tecido social tão precariamente simplória quanto uma equação de primeiro grau (ENGELS, 1967b, p. 463). Nesta conceituação não teleológica do movimento histórico, Engels dá destaque ao papel do indivíduo na história, observando o fato de que os conflitos que caracterizam a dinâmica do tecido social se estabelecem pelo movimento de um conjunto de vontades individuais que compõem forças efetivas e que se entrecruzam, sendo um grave erro teórico reduzir o grau de intervenção da figura subjetiva à zero (ENGELS, 1967b, p. 463-464).

É fato que nesse processo de delimitação do movimento da história como anti-fatalista e não excludente de um possível papel para intervenção do sujeito individual, Engels permanece com seu movimento pendular de assunção de um método vivo e uma queda ao mecanicismo (LUKÁCS, 2010, p. 118-119). Em uma carta a Borgius ${ }^{5}$, por exemplo, o autor destaca o papel do indivíduo na história, decerto 
movido por um conjunto de determinações sociais, mas passível de atuar como um vetor real (ENGELS, 1968b, p. 206). O filósofo materialista, num esforço pela fundamentação de tal afirmação, esboça inclusive uma refinada mediação entre necessidade e acaso, ao considerar que as determinações que se apresentam como necessárias são postas justamente por acasos, pela casualidade, como diria Lukács, de modo a afastar, pelo menos por hora, todo e qualquer teleologismo fatalista nesta primeira consideração. Contudo, no mesmo parágrafo, o filósofo alemão resgata a preponderância pressuposta da economicidade, que organizaria um conjunto de determinações que requeira o surgimento de um sujeito que respondesse as suas demandas, mas que, na supressão de um primeiro postulante, sua própria estrutura produziria outro que assumiria o seu lugar (ENGELS, 1968b, p. 206-207). Em outros termos, foi uma casualidade que tenha sido o indivíduo singular Napoleão aquele que desempenhou o seu papel na República francesa, mas, no caso de uma morte súbita que o tivesse impedido de exercer seus principais feitos, certamente as circunstâncias economicamente engendradas haveriam de forjar um "novo Napoleão". É claro que, em uma interpretação mais generosa, seria possível aproximar esta consideração engelsiana da perspectiva concebida por Lukács ao constatar como o cálculo diferencial foi ensaiado simultaneamente por Newton e Leibniz e esboçado por Pascal, episódio que expõe o modo como uma série de circunstâncias históricas instigam os indivíduos a assumirem simultaneamente o mesmo papel, uma vez que o ser humano é um ser que dá respostas às questões que o tecido social, e isto contribui para que surjam indivíduos que proponham a dar respostas similares a um mesmo problema (LUKÁCS, 1969, p. 63-64). Entretanto, Engels vai além, ao impor o raciocínio de que as determinações sociais produziriam tal individualidade, inevitavelmente, desviando-se de tal forma da tendencialidade do curso da história patente da filosofia da práxis e que o próprio Engels faz menção em diversos momentos. Mesmo sendo um contrapositor ardoroso do fatalismo, o próprio Engels recai em desvios fatalistas, como nas passagens d'A origem da família da propriedade privada e do Estado, onde o filósofo materialista entende que certas formas de sociabilidade podem ser encaradas como um fenômeno absolutamente geral, válido em um determinado período para todos os povos, sem distinção de lugar, (ENGELS, 1962a, p. 32).

Com relação às forças concretas que movem o conflito do tecido social, Engels vive o dilema entre a afirmação da não-mecanicidade da economia, já vista mais acima, uma manifestação gnosiológica e mecanicista da prioridade do econômico na existência humana (LUKÁCS, 2013, p. 277). Em certos momentos, Engels assume o ideológico como mero reflexo distorcido do econômico (ENGELS, 1968a, p. 97). Em outros, ele é aquele que, junto com Marx, assume o caráter desigual do desenvolvimento do ser social, a partir da constatação da reciprocidade das esferas do tecido social que vivem em constante entrecruzamento (ENGELS, 1968b, p. 206), além de argumentar que o estudo altamente concentrado na economia feito por ele por Marx nada mais seria do que uma resposta a uma tarefa histórica, devido ao escandaloso atraso do desenvolvimento da economia política do movimento operário comunista, e não como um alerta de que tal movimento aponta para a economia como o elemento inevitavelmente último de determinação do fluxo social (ENGELS, 1967b, p. 465). Contudo, por mais que ele tente fazer combate à ideia de que o fato econômico seria o determinante único da vida social, sua separação rígida entre base 
econômica e superestrutura dificulta que a sua tese da reciprocidade das esferas do tecido social se afaste plenamente de desvios mecânico-fatalistas (LUKÁCS, 2012, p. 407-408).

Lukács faz questão de apontar como a economia no interior do marxismo não pode ser vista em sua mera datidade, fruto de um imediatismo empirista, que a recorta de todos os outros componentes do tecido social (LUKÁCS, 2012, p. 291-292). Ainda em sua fase juvenil, o húngaro assevera que a especificidade do marxismo não é o papel conferido a economia, mas o ponto de vista da totalidade (LUKÁCS, 2003, p. 105). Isto se expressa na discussão que Marx e Engels apresentam n'A ideologia alemã, quando estipulam que tal como os indivíduos exteriorizam as sua vida, assim eles o são, tanto com o que produzem como também de a cordo com o modo como produzem (MARX; ENGELS, 1978, p. 21). A vida social se expressa pelo modo como ela é exteriorizada, não como uma expressão surda do econômico, mas como o econômico diz coisas que não é possível dizer sem ser acompanhado pela totalidade das determinações sociais. Marx, seguindo tais orientações, contrapõe-se a certo economicismo proudhoniano em uma passagem da Miséria da filosofia, quando diz

As relações de produção de qualquer sociedade formam um todo. O sr. Proudhon considera as relações econômicas como outras tantas fases sociais, engendrando-se umas às outras, resultando umas das outras como a antítese da tese, e realizando na sua sucessão lógica a razão impessoal da humanidade. O único inconveniente que existe nesse método é que, ao abordar o exame de uma apenas dessas fases, o sr. Proudhon não possa explicála sem que recorra a todas as outras relações da sociedade, relações que, contudo, ele ainda não originou pelo seu movimento dialético. Quando, depois disso, o sr. Proudhon por meio da razão pura passa à criação das outras fases, procede como se se tratasse de crianças recém-nascidas, esquecendo-se que têm a mesma idade da primeira [...] Quando se constrói com as categorias da economia política o edifício de um sistema ideológico, os membros do sistema social são deslocados. Os diferentes membros da sociedade são transformados em outras tantas sociedades à parte, que se sucedem umas às outras. (MARX, 1976, p. 88-89)

Assim, é importante que se diga que a economia importante indutor que traz vida ao não econômico, mas é justamente o não econômico que traduz para a realidade o que é de fato economicamente necessário, acelerando, consolidando ou até interditando a explicitação da economicidade (LUKÁCS, 2012, p. 417). É o próprio Engels que, em seus escritos militares, por exemplo, ao mostrar os diversos momentos em que é a força bélica do tecido social determina precipuamente a economia, e não contrário, recebe elogios de Marx, uma vez que tais demonstrações comprovam a perspectiva materialista defendida pela dupla (MARX, 1961a, p. 255).

Não há como estudar o complexo altamente recíproco do ser social sem apreciar no serpropriamente-assim do objeto quais são os movimentos predominantes que condicionam a sua configuração determinada, uma vez que há no marxismo uma dialética entre fato e legalidade, em que, da mesma forma que a lei só se realiza no fato, os fatos contraem feixes de determinações que tomam forma de uma especificidade concreta por meio do tipo de lei, afirmando-se nas interseções das suas interações, o que conforma um condicional, um "se... então", para cada lei (LUKÁCS, 2012, p. 338; LUKÁCS, 2013 , p. 142, 305). Assim, se a lei só se afirma no seu "se... então", ela não pode assumir nenhuma condição senão a da tendencialidade presente no andamento heterogêneo da história, sempre suscetível à rupturas, quando 
linhas causais que até então possuíam menor interferência assumem papel preponderante, fazendo com que a legalidade observada assuma uma nova faceta (LUKÁCS, 2012, p. 363).

Por conta disso, a filosofia da práxis assume que o conhecimento que as suas investigações estipulam só pode ser encarado como um conhecimento aproximativo, como caracteriza Lukács, uma vez que o aperfeiçoamento das formas investigativas, assim como o próprio movimento do real, impedem qualquer absolutização do conhecido (LUKÁCS, 2012, p. 367). Deste modo, como afirma Leandro Konder (1988, p. 15), há no marxismo uma fluidificação dos conceitos, cuja configuração e sustentação se põe de acordo com as relações materiais das quais são criaturas, e, justamente por esta característica, são tão pouco eternas como as relações que as exprimem, consolidando-se como produtos históricos e transitórios (MARX, 1976, p. 88).

Engels atesta tais considerações situando a atividade do pensamento humano na história, inviabilizando a ideia de uma chamada verdade eterna, não só pela vacilação desse objeto, mas também porque o pensar do indivíduo insere-se num decurso que se movimenta a partir das contribuições de muitos bilhões de seres humanos do passado, entendendo também que a imensurabilidade do futuro que escapará a linha investigativa do próprio sujeito individual, o que demonstra a incompletude do material histórico investigativo e do próprio objeto investigado (ENGELS, 1975b, p. 79-84). Em Ludwig Feuerbach e o fim da filosofia clássica alemã, Engels dá continuidade a tal entendimento ao conceber que, para o marxismo, a partir das contribuições hegelianas criticamente apropriadas, o pensamento não pode apreender o mundo como um conjunto de coisas acabadas, mas como um conjunto de processos em que, embora as coisas pareçam estáveis, há um intenso processo de surgimento, transformação e caducidade, de modo que perde sentido a antítese irredutível da velha metafísica entre o verdadeiro e o falso (ENGELS, 1962b, p. 293-294), uma vez que o processo histórico descortina diversas facetas ocultadas pela gerações precedentes, de mesma forma que aquilo que se percebe como evidente no tempo presente pode ser recusado pelo avanço científico de tempos futuros, acabando com as pretensões das soluções definitivas das verdades eternas, limitando os resultados que nós obtemos às condições e circunstâncias de nossa época.

\section{O método como ciência ordenadora}

Torna-se inadequado, por tudo o que já foi exposto, o raciocínio que concebe a adesão ao método marxista como critério de verdade, como se ocorresse uma corretude automática no processo investigativo pura e simplesmente segundo o fato de que uma pesquisa é regida pelo marxismo. Como argumenta Ivo Tonet (2013, p. 125), é a vinculação ontológica das teses extraídas pelo estudo com o movimento efetivo do objeto que estabelece a melhor resposta para determinada questão teórica, e não um tribunal da razão que estabelece a verdade pelo critério do caráter marxista ou não de uma pesquisa. Lefebvre explicita isso ao trabalhar com o exemplo dado por Descartes e Gassendi nas discussões da filosofia francesa do século XVII (LEFEBVRE, 1991, p. 61). Aos olhos de um sujeito de nosso tempo, que pode lidar com os avanços filosóficos e científicos que ocorreram nos últimos 350 anos, é patente que não só o método de Gassendi é mais compatível com o nosso, como as críticas que ele nutria com relação à perspectiva do racionalista eram 
certamente plausíveis. Contudo, as conquistas de Descartes para a filosofia, assim como as suas colaborações para a álgebra, para a geometria analítica e para o entendimento do fenômeno da refração foram contribuições mais robustas que a do materialista francês. Não há um automatismo entre a maior acurácia de um método empregado e as contribuições que um estudo pode apresentar, justamente porque existem determinantes na individualidade daqueles que pesquisam, nas condições materiais imediatas disponíveis, nas circunstâncias histórico-gerais envolvidas e no próprio automovimento do objeto estudado que influem na condução da investigação. A fetichização do método forma uma espécie de deslumbramento nocivo, um importante obstáculo para a pesquisa, por estimular o agente a ignorar contribuições de outras linhas teóricas e, em casos mais graves, o próprio ser efetivo do objeto acompanhado, mantendo o andamento da iniciativa teórica pura e simplesmente segundo a manipulação das categorias reificadas do método adotado.

Marx, de acordo com um depoimento de Engels, ao ver um conjunto de indivíduos reivindicando serem marxistas como forma de se liberar do estudo dos seus objetos em suas especificidades, por entenderem que a mera adesão ao marxismo já asseguraria a correção de seus juízos, como se houvesse uma natureza oracular no marxismo, afirmou ironicamente que "tudo que eu sei é que não sou marxista" (ENGELS, 1967a, p. 436). Como já foi aludido acima, a resposta engelsiana a esse tipo de pseudoortodoxia arbitrária é o uso da teoria como ferramenta de estudo do objeto nos nexos causais que se formam em sua existência concreta. Justamente por isso, tanto ele quanto Marx escreveram que vinte e quatro anos após a primeira edição do Manifesto do partido comunista boa parte das circunstâncias históricas analisadas não tinham mais validade alguma (MARX; ENGELS, 1976, p. 95-96). Isto não impediu, como Engels aponta em outro texto, que as reflexões criadas pela dupla alemã tenham construído um indicador da tendencialidade do desenvolvimento do objeto estudado (ENGELS, 1977, p. 282).

Assim, como Lukács indica, a ortodoxia do marxismo não reside em uma espécie de profissão de fé nos resultados obtidos pelos seus iniciadores, como se fosse necessário para ser marxista uma leitura da dogmática e talmúdica das suas primeiras manifestações, cristalizando-as (LUKÁCS, 2013, p. 63-64). O húngaro chega a afirmar que, para o marxismo, não haveria o menor problema em assumir a caducidade de qualquer tese de Marx e Engels devido o avanço da ciência e/ou a alteração do material estudado. O marxismo ortodoxo não é um culto laico a esta dupla de filósofos. A ortodoxia se refere justamente ao método, ao quadro categorial engendrado por eles que permite uma investigação mais adequada. $\mathrm{O}$ problema não estaria em romper com algo que Marx e Engels disseram, mas sim numa a sustentação religiosa de uma de suas teses mesmo que o movimento real do objeto aponte para outro caminho, atitude que os dois filósofos lutaram para não fazer. Marx, inclusive, dizia que o lema de sua vida seria "duvide de tudo" (RIAZANOV, 1984, p. 133, 141), não como uma ode a um tipo de ceticismo que nega a possibilidade de qualquer tipo de posição ou resultado parcial, mas como orientação para que a indagação do objeto nunca cesse, pois a paralisia do objeto só existe como hipóstase arbitrária da imaginação humana.

O método, neste sentido, nada mais é do que o processo de obter conhecimentos novos a partir de conhecimentos já adquiridos, isto é, a penetração no desconhecido a partir do conhecido (LEFEBVRE, 1991, p. 150). O método atua como uma forma de imediato supremo, que estão nas mãos do investigador antes de tudo, legitimando-se como um imediato não arbitrário justamente por ser atravessado por todas as 
mediações possíveis, absorvendo o conjunto das manifestações apresentadas ao longo do devir do tempo, tornando-se universal concreto (LEFEBVRE, 1991, p. 237, 271). O filósofo brasileiro Hector Benoit (1996, p. 21-22), ciente de tal compreensão, admite que o método para o marxismo compreende que o avançar em direção ao conhecimento também exige um movimento de retroação, na medida em que se emprega este movimento retrocedente como uma volta aos fundamentos, ao acúmulo originário do qual o começo da investigação torna-se dependente. Assim, como Engels argumenta, a elaboração do método no marxismo não conforma uma ciência metafísica, que apenas coleciona fatos acabados, mas sim uma ciência ordenadora (ordnende Wissenschaft), que, no múltiplo enriquecimento das determinações precedentes, extrai um norte teórico que não vale por si só, dependendo de um uso concreto que permita a apropriação efetiva do objeto (ENGELS, 1962b, p. 294).

Em suma, o grande trunfo do método no marxismo, como Marx e Engels asseveram n'A ideologia alemã é a dissolução da teoria especulativa, que cede lugar a um conjunto de resoluções metodológicas que atuam como a súmula (Zusammenfassung) do desenvolvimento histórico (MARX; ENGELS, 1978, p. 27), fundamento indispensável para a investigação, uma vez que, sem ele, não há a ordenação do material histórico que possibilita a apreensão da sequência de cada um de seus extratos. Contudo, tal síntese deve estar a todo momento envolvida com o devir desse objeto. Caso contrário, e esse se encontre apartado de tal movimento, a sua riqueza conceitual é dissolvida. A síntese metodológica que parte da teoria de Marx e Engels, do que pode ser depreendido dos argumentos expostos, é que os méritos de um método estão no uso que ele faz das próprias categorias do seu objeto, este sim, o real critério de verdade de uma investigação.

\section{Referências:}

BENOIT, H. Sobre a crítica (dialética) de O capital. In: Revista Crítica Marxista número 03. São Paulo: Editora Brasiliense, 1996, p. 14-45.

BERNSTEIN, E. Socialismo evolucionário. Rio de Janeira: Zahar, 1997.

BERNSTEIN, E. The preconditions of socialism. Cambridge: Cambridge University Press, 1993.

CHASIN, J. Estatuto ontológico e resolução metodológica. São Paulo: Boitempo, 2009.

ENGELS, F. Anteil der Arbeit an der Menschwerdung des Affen. In: MARX, K; ENGELS, F. MarxEngels Werke - band 20. Berlin: Dietz Verlag Berlin, 1975a.

ENGELS, F. Anti-Dühring. In: MARX, K; ENGELS, F. Marx-Engels Werke - band 20. Berlin: Dietz Verlag Berlin, 1975b.

ENGELS, F. Der Ursprung der Familie, des Privateigentums und des Staats. In: MARX, K; ENGELS, F. Marx-Engels Werke - band 21. Berlin: Dietz Verlag Berlin, 1962a.

ENGELS, F. Dialektik der Natur. In: MARX, K; ENGELS, F. Marx-Engels Werke - band 20. Berlin: Dietz Verlag Berlin, 1975c.

ENGELS, F. Engels an Conrad Schmidt 5. August 1890. In: MARX, K; ENGELS, F. Marx-Engels

Werke - band 37. Berlin: Dietz Verlag Berlin, 1967a.

ENGELS, F. Engels an Franz Mehring 14. Juli 1893. In: MARX, K; ENGELS, F. Marx-Engels Werke band 39. Berlin: Dietz Verlag Berlin, 1968a. 
ENGELS, F. Engels an Joseph Bloch 21. oder 22. September 1890. In: MARX, K; ENGELS, F. MarxEngels Werke - band 37. Berlin: Dietz Verlag Berlin, $1967 \mathrm{~b}$.

ENGELS, F. Engels an Marx 11. oder 12. Dez. 1859. In: MARX, K; ENGELS, F. Marx-Engels Werke - band 29. Berlin: Dietz Verlag Berlin, 1978.

ENGELS, F. Engels an Marx 19. Dez. 1882. In: MARX, K; ENGELS, F. Marx-Engels Werke - band 35. Berlin: Dietz Verlag Berlin, 1967c.

ENGELS, F. Engels an W. Borgius 25. Janua 1894. In: MARX, K; ENGELS, F. Marx-Engels Werke band 39. Berlin: Dietz Verlag Berlin, 1968b.

ENGELS, F. Karl Marx, Zur Kritik der Politischen Ökonomie. In: MARX, K; ENGELS, F. MarxEngels Werke - band 13. Berlin: Dietz Verlag Berlin, 1961.

ENGELS, F. Ludwig Feuerbach und der Ausgang der klassischen deutschen Philosophie. In: MARX, K; ENGELS, F. Marx-Engels Werke - band 21. Berlin: Dietz Verlag Berlin, 1962b.

ENGELS, F. Vobemerkung zu der deustche Bauernkrieg (ausgabe 1870 und 1875). In: MARX, K; ENGELS, F. Marx-Engels Werke - band 7. Berlin: Dietz Verlag Berlin, 1960.

ENGELS, F. Vorwort zur zweiten polnischen Ausgabe (1892) des Manifests der Kommunistischen Partei. In: MARX, K; ENGELS, F. Marx-Engels Werke - band 22. Berlin: Dietz Verlag Berlin, 1977.

FREIRE JR., O. Friedrich Engels e as ciências da natureza. In: Revista Princípios, no 39, nov. 1995, p. 28-33.

HEGEL, G. W. F. Ciência da lógica - 1. A doutrina do ser. Petrópolis: Vozes, 2016.

HEGEL, G. W. F. Ciência da lógica - 3. A doutrina do conceito. Petrópolis: Vozes, 2018.

HEGEL, G. W. F. Enciclopédia das ciências filosóficas em compêndio (1830): Volume I - A ciência da lógica. São Paulo: Loyola, 2007a.

HEGEL, G. W. F. Fé e saber. São Paulo: Hedra, 2007b.

HEGEL, G. W. F. Fenomenologia do espírito. Petrópolis: Vozes, 2014.

HEGEL, G. W. F. Princípios da filosofia do direito. São Paulo: Martins Fontes, 2000.

KONDER, L. A derrota da dialética. Rio de Janeiro: Campus, 1988.

KONDER, L. Lukács. Porto Alegre: L\&PM, 1980.

KONDER, L. Os marxistas e a arte. São Paulo: Expressão Popular, 2013.

LA CHINOISE. Direção: Jean-Luc Godard. Moema, MG: Silver Screen Collection, 1967. 96 m, color.

LEFEBVRE, H. Lógica formal/lógica dialética. Rio de Janeiro: Civilização Brasileira, 1991.

LUKÁCS, G. As bases ontológicas do pensamento e da atividade do homem. In: O jovem Marx e outros escritos de filosofia. Rio de Janeiro: Editora UFRJ, 2007.

LUKÁCS, G. Essenciais são os livros não escritos. São Paulo: Boitempo, 2020.

LUKÁCS, G. História e consciência de classe: estudos sobre a dialética marxista. São Paulo: WMF Martins Fontes, 2003.

LUKÁCS, G. Literatura e vida. In: Conversando com Lukács. Rio de Janeiro: Paz e Terra, 1969.

LUKÁCS, G. O processo de democratização. In: Socialismo e democratização. Rio de Janeiro: Editora UFRJ, 2011.

LUKÁCS, G. Para uma ontologia do ser social I. São Paulo: Boitempo, 2012.

LUKÁCS, G. Para uma ontologia do ser social II. São Paulo: Boitempo, 2013.

LUKÁCS, G. Pensamento Vivido. São Paulo: Instituto Lukács, 2017.

LUKÁCS, G. Prolegômenos para uma ontologia do ser social. São Paulo: Boitempo, 2010. 
LUKÁCS, G. Reboquismo e dialética. São Paulo: Boitempo, 2015.

MARX, K. Carta a Engels 25 de setembro de 1857. In: MARX, K; ENGELS, F. Obras escolhidas volume 3. São Paulo: Alfa-Omega, 1961a.

MARX, K. Cartas dos Anais franco-alemães. In: Sobre a questão judaica. São Paulo: Boitempo, 2010.

MARX, K. Grundrisse. São Paulo: Boitempo; Rio de Janeiro, Editora UFRJ, 2011.

MARX, K. Manuscritos econômico-filosóficos. In: Cadernos de Paris; Manuscritos econômicofilosóficos. São Paulo: Expressão Popular, 2015.

MARX, K. Marx to Engels 7 july 1866. In: MARX, K; ENGELS, F. Collected works - volume 42. New York: International Publishers, 1987.

MARX, K. Miséria da filosofia. Porto: Publicações Escorpião, 1976.

MARX, K. O Capital: crítica da economia política - volume I. São Paulo: Nova Cultural, 1988.

MARX, K. Teses sobre Feuerbach. In: MARX, K.; ENGELS, F. A ideologia alemã. São Paulo: Expressão Popular, 2009.

MARX, K.; ENGELS, F. Die deutsche Ideologie. In: Marx-Engels Werke - band 3. Berlin: Dietz Verlag Berlin, 1978.

MARX, K.; ENGELS, F. Vorwort zum Manifest der Kommunistischen Partei (deutsche Ausgabe 1872). In: Marx-Engels Werke - band 18. Berlin: Dietz Verlag Berlin, 1976.

MÜLLER, M. L. Exposição e método dialético em O capital. Extraído do Boletim Seaf, no 2, Belo Horizonte, 1982, p. 1-15.

RIAZANOV, D. A “confissão” de Karl Marx. In: Marx: o homem, o pensador, o revolucionário. São Paulo: Global, 1984.

SEMPRÚN, J. Um belo domingo. São Paulo: Nova Fronteira, 1982.

TONET, I. Método científico: uma abordagem ontológica. São Paulo: Instituto Lukács, 2013.

\section{Notas}

${ }^{1}$ PPGF UFBA. Professor de Filosofia na rede estadual de educação básica na Bahia. Licenciado em Filosofia pela Universidade Federal da Bahia e mestrando no Programa de Pós-Graduação em Filosofia da mesma instituição. Currículo Lattes: http://lattes.cnpq.br/0420195950695960 Orcid: http://orcid.org/0000-0002-2247-4632 E-mail: andrefbrandao96@gmail.com

2 Durante o governo de Stalin, cuja direção cultural era encabeçada por Andrei Jdanov, o hegelianismo foi tomado por filosofia inerentemente conservadora, na contramão das teses engelsianas, tornando o repúdio ao sistema do pensador de Sttutgart doutrina oficial. Foi por conta de tal engessamento que Lukács demorou dez anos para publicar o seu livro O jovem Hegel e os problemas da sociedade capitalista (LUKÁCS, 2020, p. 162).

${ }^{3}$ Marx e Engels nutriam uma clara aversão à Comte e ao positivismo. Um exemplo disso se encontra numa carta de Marx a Engels de 7 de julho de 1866, na qual o mouro, extremamente queixoso, resmunga que o "desprezível e inútil positivismo apareceu em 1832” (MARX, 1987, p. 34). Ao contrário dos pensadores alemães, o marxismo soviético sob o governo de Stalin aproximou-se dos contornos positivistas suficientemente para que Máximo Górki, célebre literato russo, se sentisse confortável para propor, à imagem e semelhança da igreja positiva concebida por Comte, uma religião marxista, como veículo mais fácil de difusão das teses marxistas, projeto que felizmente não foi adiante (KONDER, 2013, p. 85)

${ }^{4} \mathrm{O}$ termo ser-propriamente-assim é um conceito cunhado pelo último Lukács que não é utilizado por Marx e Engels nas suas obras originais, mas tem um grande potencial elucidativo para as resoluções metodológicas da dupla alemã, acerca da prioridade do objeto no processo de investigação e da necessidade de estuda-lo em sua dinâmica efetiva, e não segundo os apriorismos da imaginação daquele que o estuda.

${ }^{5}$ Embora esta carta seja conhecida por muitos como uma carta endereçada à Heinz Starkenburg, Como informa a nota explicativa número 245 da $M E W$-Band 39, isto nada mais é do que um erro editorial repetido em massa, devido ao fato de que Starkenburg foi um grande difusor do conteúdo do escrito, publicando-a em periódico socialista um ano depois da sua redação. 